\title{
Diet, alcohol, and relative weight in gall stone disease: a case-control study
}

\author{
R K R SCRAGG, A J McMICHAEL, P A BAGHURST
}

\begin{abstract}
A case control study of gall stone disease in relation to diet, alcohol, and relative weight was undertaken. The study population comprised 267 hospital patients with newly diagnosed gall stone disease, 241 individually matched controls selected from the community, and 359 controls who were patients in hospital. Dietary intake was estimated with a quantitative food frequency questionnaire. Multiple logistic regression analysis was used to estimate the net association between individual nutrients and the risk of formation of gall stones. Variations in risk with sex and age were examined in the light of prior evidence of influences of sex hormones and age on hepatobiliary metabolism.

In both sexes increased intake of alcohol was associated with a decreased risk of developing gall stones; increased intake of simple sugars in drinks and sweets was associated with an increased risk; and increased intake of energy or fat was associated with an increased risk in young subjects. Obesity was associated with an increased risk only in young women.
\end{abstract}

\section{Introduction}

The appreciable variations in the prevalence of gall stones between countries and over time ${ }^{1}$ suggest that lifestyle may have an aetiological role. Diet is likely to be important as the intake

Division of Human Nutrition, Commonwealth Scientific and Industrial Research Organisation, Adelaide, South Australia 5000

R K R SCRAGG, MB, BS, research fellow in epidemiology (also honorary registrar, Department of Surgery, Flinders Medical Centre, South Australia)

A J MCMICHAEL, MB, PHD, senior principal research scientist

P A BAGHURST, MSC, PHD, senior research scientist

Correspondence and requests for reprints to: Dr R K R Scragg, Department of Community Health, School of Medicine, University of Auckland, Auckland, New Zealand. of, for example, energy, cholesterol, polyunsaturated fat, and fibre affect the cholesterol saturation of bile. ${ }^{2}$

Results from case-control studies investigating the association of diet with gall stone disease have not been consistent. ${ }^{3-13}$ Basic criticisms of these studies are that many used inadequate sample sizes as reflected by published standard errors ${ }^{7810}$; many studied controls only from hospitals, who, because they had disorders possibly related to diet, were probably not representative of people without gall stones $^{347-911}$; many studied patients with longstanding gall stone disease, who were more likely than patients with newly diagnosed gall stone disease to have changed their diet because of symptoms or treatment ${ }^{10-13}$; and many used unsatisfactory methods for assessing diet. ${ }^{3-6} 81112$

We report a case-control study of 267 patients who had recently developed gall stone disease and of two groups of controls, one comprising patients in the hospital and one comprising people in the community. We examined the risk of gall stone disease in relation to the intake of energy and fat, to obesity, and to consumption of alcohol. The possibility that the strength of aetiological relations would decrease with increasing age, reflecting the progressive depletion in the number of subjects metabolically susceptible to gall stones, ${ }^{14}$ was also examined.

\section{Subjects and methods}

\section{SELECTION OF SUBJECTS}

From December 1978 to September 1980, 867 subjects aged 70 or under from hospitals and the community entered the study. Hospital patients were from two of the three major public hospitals in Adelaide. They were interviewed blind when presenting for oral cholecystography or ultrasound of the gall bladder after referral for diagnosis of abdominal symptoms $(\mathbf{n}=508)$, before gastric bypass for obesity $(n=37)$, or because of prior disease (for example, pancreatitis) $(n=58)$. Those who were subsequently found to have stones visible in their cholecystogram or ultrasound scan and those whose cholecystograms did not show any opacity but in whom stones were confirmed at operation entered the study as patients. Those found not to have gall stones served as hospital controls.

Because most of the hospital controls had symptoms that may have arisen from disorders related to diet, they could not be assumed to be 
representative of people without gall stones in the source population. Accordingly, we also studied a group of controls from the community, randomly selected from the electoral roll (registration as a voter is compulsory). They were individually matched with patients for sex, age (within two years), and residential area. Those with a history of gall stones or related symptoms were excluded and replaced with another control. The response among community controls was $81 \%$.

There were some socioeconomic differences between patients and community controls because patients came only from public hospitals whereas community controls, though sharing the same residential area as patients, came from the total population treated by both public and private medical systems. Socioeconomic confounding between patients and community controls was assessed.

The study population comprised 267 patients, of whom 241 were successfully matched with community controls, and 359 hospital controls (table I). The hospital controls who had symptoms suggestive

TABLE I-Numbers of patients, hospital controls, and community controls included in data analysis

\begin{tabular}{lrrr}
\hline & Men & Women & Total \\
\hline Patients: & & & \\
Matched with community controls & 59 & 182 & 241 \\
Unmatched & 8 & 18 & 26 \\
\hline Total No of patients & 67 & 200 & 267 \\
\hline Hospital controls & 125 & 234 & 359 \\
Community controls & 59 & 182 & 241 \\
\hline Overall total & 251 & 616 & 867 \\
\hline
\end{tabular}

of gall stones were subsequently found to have the following disorders: acalculous gall bladder disease (nine women, eight men); pancreatitis (nine, 17); hepatitis (one, one); hiatus hernia (eight, five); peptic ulcers or inflammation $(11,14)$; and disease of the small or large bowel (six, four). One hundred and sixty six women $(78 \%)$ and 65 men $(54 \%)$ had abdominal pain for which no cause was found during a period of six months or more after entry into the study. Some of them may have had gall stones that were not detected because of the imperfect sensitivity of oral cholecystography ${ }^{15-17}$ or were passed during an attack of biliary colic before $x$ ray examination. ${ }^{18} 19$

\section{COLLECTION OF DATA}

Data were collected from each subject during two interviews by one of us (RKS). At the first interview subjects were questioned, according to a structured format, on their history of body weight, medical conditions, and pregnancy, prescribed drug usage, family history of gall stones, and demographic background. The weight and height of each subject were measured. After this first interview the subjects were given, with a careful explanation, a copy of our dietary questionnaire to take home and complete in their own time. The questionnaires were checked for completeness at a second interview.

Patients and controls in hospital were interviewed in a different setting from community controls. Typically, subjects in hospital were interviewed double blind and fasting in hospital in the morning and were wearing underclothes under a hospital gown. Community controls were interviewed at home, usually after an evening meal, and were wearing light clothes when weighed. Community controls were told the purpose of the study, in the same general terms as hospital subjects, but were not informed of the specific hypotheses behind the study.

\section{DIETARY QUESTIONNAIRE}

We used the food frequency method, as developed by us, ${ }^{20}$ to measure individual dietary intake; this method is generally considered to give a more accurate estimate of usual intake than methods such as the diet diary or dietary recall. ${ }^{20-22}$ The list of foods comprised 105 individual items; subjects marked the frequency of consumption of each item. Subjects were asked to recollect their usual dietary intake over several months before interview. Subsequent analysis showed dietary intake of major nutrients to be unrelated to the duration or type of symptoms of gall stones experienced by patients.

For each item of food the number or fraction of helpings each day was multiplied by the nutrient content of an average helping, as estimated from recently published food tables, ${ }^{23}$ and then scaled by the ratio of the size of the meal recorded for each subject relative to the standard size of helpings reported for Australian meals. ${ }^{24}$ The size of helpings of meat (or fish) was estimated with plastic replicas; the size of helpings of vegetables was estimated with a combination of real potato, carrots, and peas; the size of helpings of dessert was estimated with uniform slices of a finely textured (water absorbent) sponge; and the size of glasses used was estimated with a $250 \mathrm{ml}$ glass being taken as the medium category. The sum of the scaled values for each nutrient was used in subsequent dietary analyses.

\section{STATISTICAL ANALYSES}

The $t$ test for independent samples was used to compare means for patients and controls. ${ }^{25}$ The ratio of the discordant matched pairs was used to calculate odds ratios for patients and their matched community controls, and confidence limits were computed from the binomial distribution. ${ }^{26}$

Multiple logistic regression was used to estimate the net association between individual variables and the risk of gall stones developing after other confounding variables had been controlled for. Regression coefficients were estimated by the method of maximum likelihood, ${ }^{27}$ and standardised coefficients were calculated by dividing a regression coefficient by its standard of error. Model building proceeded by forward selection; the likelihood ratio test was used to determine the goodness of fit. All variables were treated as continuous; nonlinear relations between individual variables and the probability of gall stone formation were investigated by transformations and by interaction terms.

After preliminary examination of trends in relative risk related to decades of ages patients were divided into those aged 50 and over and those aged below 50 as in women this age coincides with (menopausal) changes in sex hormone concentrations, which influence hepatic lipid metabolism. Furthermore, there were roughly similar numbers of subjects in the study in these two age groups.

\section{Results}

\section{UNIVARIATE ANALYSIS OF DIET}

The mean daily intake of energy, total fat, cholesterol, protein, starch (polysaccharides), and total sugar (monosaccharides and disaccharides) by female patients aged less than 50 was greater than that by their matched community controls, whereas consumption of these nutrients by female patients aged 50 or over tended to be lower than that by matched community controls (table II). There was a similar pattern among men, with male patients under 50 tending to have a greater intake of these same nutrients, and patients aged 50 and over to have a lower intake, than their respective matched community controls (table II). Prior analysis had shown that this reversal of effect, below and above the age of 50, summarised a graduated reduction with increasing decades of age in the risk of development of gall stones related to intake of nutrients.

The increased intake of total sugar by young patients of both sexes compared with matched community controls was largely due to increased consumption of sugar in drinks (tea, coffee, cordial, and aerated soft drinks) and sweets (jam, honey, chocolate, and other confectionery). Intake of sugar in drinks and sweets was also greater in older patients than in their matched controls (table II). Consumption of sugar, however, from all other food sources (unsweetened and sweetened cereal products, fruit, and dairy products) was the same for patients and controls in all age and sex groups. The ratio of polyunsaturated fats to saturated fats was similar for patients and community controls in all groups.

Mean daily consumption of alcohol was significantly $(p<0.05)$ lower among female patients in both age groups compared with their matched community controls and slightly, but not significantly, lower in male patients than in their matched controls (table II). In both men and women, however, a much lower proportion of patients than controls drank alcoholic drinks. Using this criterion, the matched pairs odds ratio associated with drinking alcohol for women of all ages was $0.4(95 \%$ confidence limits $=0.2,0.6)$ and for men was $0 \cdot 1(95 \%$ confidence limits $=0 \cdot 002,0 \cdot 6)$. 
BRITISH MEDICAL JOURNAL VOLUME $288 \quad 14$ APRIL 1984

Among the patients and hospital controls mean daily intake of nutrients was unrelated to reason for referral for biliary radiological examination. Comparison of the mean daily nutrient intake of patients with that of hospital controls showed that the differences between female patients and hospital controls were generally in the sane direction, though not as large, as those between female patients and community controls (table III). In women under 50 intake of all nutrients, except alcohol, was greater, though not significantly so, in patients than hospital controls, though there was little or no difference in nutrient intake between female patients and hospital controls aged 50 and above. Among men in both age groups intake of all nutrients was lower in patients than controls, although no differences were significant $(p>0.05)$.

\section{MULTIVARIATE ANALYSIS OF DIET}

Because the estimated intakes of all the major nutrients, apart from alcohol and sugar in drinks and sweets, were significantly correlated with each other and with total intake of energy, multiple logistic regression was carried out to estimate the net association between each nutrient and the risk of development of gall stones.

Tablc IV lists the best fitting set of alternative dietary models, with the regression coefficients for the individual nutrients derived from the data sets for female and male patients and community controls. Energy and fat were included in separate models as they were highly collinear, as was sugar in drinks and sweets with both total sugar and fibre. Energy and total sugar were also highly collinear as neither variable had a significant $(p<0.05)$ regression coefficient when included in the same model. Transformation to the natural logarithm of alcohol intake by women and men, and of fibre intake by men, significantly $(p<0.05)$ improved the goodness of fit.

The direction of the regression coefficients in table IV shows that, for both sexes total sugar and sugar in drinks and sweets were positively associated with the risk of developing gall stones; alcohol, cholesterol (in women), and fibre were negatively associated with the risk; and energy and fat had significant age interaction terms that were negatively associated with development of gall stones. All associations in table IV were independent of obesity (as defined by Quetelet's index), socioeconomic state (as estimated by household income), nationality, and parity, except for intake of alcohol in

TABLE II-Mean (SE) daily intake of major nutrients by matched patients and community controls

\begin{tabular}{|c|c|c|c|c|c|c|c|c|}
\hline \multirow{3}{*}{ Nutrients ${ }^{23}$} & \multicolumn{4}{|c|}{ Women } & \multicolumn{4}{|c|}{ Men } \\
\hline & \multicolumn{2}{|c|}{ Aged $<50$} & \multicolumn{2}{|c|}{ Aged $\geqslant 50$} & \multicolumn{2}{|c|}{ Aged $<50$} & \multicolumn{2}{|c|}{ Aged $\geqslant 50$} \\
\hline & $\begin{array}{l}\text { Patients } \\
(\mathrm{n}=107)\end{array}$ & $\begin{array}{l}\text { Controls } \\
(n=107)\end{array}$ & $\begin{array}{l}\text { Patients } \\
(\mathrm{n}=69)\end{array}$ & $\begin{array}{l}\text { Controls } \\
(n=69)\end{array}$ & $\begin{array}{l}\text { Patients } \\
(\mathrm{n}=24)\end{array}$ & $\begin{array}{l}\text { Controls } \\
(n=24)\end{array}$ & $\begin{array}{l}\text { Patients } \\
(\mathrm{n}=33)\end{array}$ & $\begin{array}{l}\text { Controls } \\
(\mathrm{n}=33)\end{array}$ \\
\hline $\begin{array}{l}\text { Energy (MJ) } \\
\text { Total fat (g) } \\
\text { Cholesterol (mg) } \\
\text { Protein (g) } \\
\text { Starch (g) } \\
\text { Sugar (g): }\end{array}$ & $\begin{array}{l}8 \cdot 32(0 \cdot 28) \ddagger \\
84(3)_{\ddagger}^{\ddagger} \\
284(15)^{*} \\
76(3) \ddagger \\
95(5)^{*}\end{array}$ & $\begin{array}{l}6 \cdot 85(0 \cdot 2) \\
68(2) \\
244(11) \\
64(2) \\
80(3)\end{array}$ & $\begin{array}{c}7 \cdot 03(0 \cdot 31) \\
68(4) \\
235(12)^{*} \\
62(3) \\
86(5)\end{array}$ & $\begin{array}{l}7 \cdot 55(0 \cdot 34) \\
75(4) \\
287(18) \\
69(3) \\
90(7)\end{array}$ & $\begin{array}{l}9 \cdot 85(0 \cdot 81) \\
98(10) \\
343(45) \\
93(12) \\
111(12)\end{array}$ & $\begin{array}{c}8 \cdot 7(0 \cdot 41) \\
89(5) \\
299(21) \\
81(6) \\
110(9)\end{array}$ & $\begin{array}{c}8 \cdot 28(0 \cdot 5)^{*} \\
84(5)^{*} \\
326(24) \\
74(4) \\
91(7) \dagger\end{array}$ & $\begin{array}{l}10 \cdot 2(0 \cdot 58) \\
105(7) \\
354(24) \\
86(4) \\
129(12)\end{array}$ \\
\hline $\begin{array}{l}\text { Sugar }(g): \\
\text { Total } \\
\text { Drinks and sweets } \\
\text { Fibre }(g) \\
\text { Alcohol }(g)\end{array}$ & $\begin{array}{c}147(7) \ddagger \\
53(4) \ddagger \\
19 \cdot 2(0.8) \\
3.0(0.6)\end{array}$ & $\begin{array}{l}113(4) \\
28(3) \\
17 \cdot 7(0.7) \\
5.7(0.9)\end{array}$ & $\begin{array}{l}128(8) \\
36(4) \dagger \\
18 \cdot 1(0.9) \\
2 \cdot 6(0.6)^{*}\end{array}$ & $\begin{array}{l}126(7) \\
23(2) \\
21 \cdot 9(1 \cdot 2) \\
4 \cdot 6(0 \cdot 8)\end{array}$ & $\begin{array}{l}160(15)^{*} \\
58(5)^{*} \\
17 \cdot 4(2 \cdot 1) \\
10 \cdot 7(4 \cdot 0)\end{array}$ & $\begin{array}{l}121(10) \\
40(7) \\
18 \cdot 3(1 \cdot 6) \\
11 \cdot 5(2 \cdot 9)\end{array}$ & $\begin{array}{l}135(12) \\
46(6) \\
18 \cdot 5(2 \cdot 2) \\
10 \cdot 1(3 \cdot 8)\end{array}$ & $\begin{array}{l}153(10) \\
40(5) \\
22.6(1 \cdot 9) \\
11.9(3.3)\end{array}$ \\
\hline
\end{tabular}

Patients significantly different from matched controls: ${ }^{*} \mathrm{p}<0.05 ; \mathrm{p}<0.01 ; \ddagger \mathrm{p}<0.001$.

Conversion: SI to traditional units-Energy: $1 \mathrm{MJ} \approx 239 \mathrm{kcal}$.

TABLE III-Mean (SE) daily intake of major nutrients by patients and hospital controls*

\begin{tabular}{|c|c|c|c|c|c|c|c|c|}
\hline \multirow{3}{*}{ Nutrients ${ }^{23}$} & \multicolumn{4}{|c|}{ Women } & \multicolumn{4}{|c|}{ Men } \\
\hline & \multicolumn{2}{|c|}{ Aged $<50$} & \multicolumn{2}{|c|}{ Aged $\geqslant 50$} & \multicolumn{2}{|c|}{ Aged $<50$} & \multicolumn{2}{|c|}{ Aged $\geqslant 50$} \\
\hline & $\begin{array}{l}\text { Patients } \\
(\mathrm{n}=117)\end{array}$ & $\begin{array}{l}\text { Controls } \\
(n=141)\end{array}$ & $\begin{array}{l}\text { Patients } \\
(\mathrm{n}=73)\end{array}$ & $\begin{array}{l}\text { Controls } \\
(\mathrm{n}=70)\end{array}$ & $\begin{array}{l}\text { Patients } \\
(n=28)\end{array}$ & $\begin{array}{l}\text { Controls } \\
(n=66)\end{array}$ & $\begin{array}{l}\text { Patients } \\
(\mathrm{n}=37)\end{array}$ & $\begin{array}{l}\text { Controls } \\
(n=45)\end{array}$ \\
\hline $\begin{array}{l}\text { Energy (MJ) } \\
\text { Totgl fat (g) } \\
\text { Cholesterol (mg) } \\
\text { Protein (g) } \\
\text { Starch (g) } \\
\text { Sugar (g): }\end{array}$ & $\begin{array}{c}8 \cdot 38(0 \cdot 27) \\
85(3) \\
289(15) \\
76(2) \\
96(5)\end{array}$ & $\begin{array}{c}7 \cdot 82(0 \cdot 31) \\
80(4) \\
284(12) \\
72(2) \\
87(4)\end{array}$ & $\begin{array}{c}7 \cdot 02(0 \cdot 31) \\
68(4) \\
240(12) \\
62(3) \\
85(5)\end{array}$ & $\begin{array}{c}6 \cdot 78(0 \cdot 31) \\
66(4) \\
236(14) \\
62(3) \\
77(4)\end{array}$ & $\begin{array}{l}9 \cdot 97(0 \cdot 72) \\
99(9) \\
345(40) \\
93(11) \\
120(12)\end{array}$ & $\begin{array}{l}10 \cdot 99(0 \cdot 48) \\
116(6) \\
426(27) \\
103(5) \\
135(9)\end{array}$ & $\begin{array}{c}8 \cdot 3(0 \cdot 46) \\
85(5) \\
323(22) \\
74(4) \\
93(7)\end{array}$ & $\begin{array}{c}9 \cdot 2(0 \cdot 58) \\
95(7) \\
363(29) \\
81(5) \\
104(8)\end{array}$ \\
\hline $\begin{array}{l}\text { Total } \\
\text { Drinks and sweets } \\
\text { Fibre }(\mathbf{g}) \\
\text { Alcohol }(\dot{g})\end{array}$ & $\begin{array}{l}148(7) \\
52(4) \\
19 \cdot 4(0 \cdot 8) \\
3 \cdot 0(0 \cdot 6)\end{array}$ & $\begin{array}{l}133(6) \\
45(4) \\
17 \cdot 8(0 \cdot 8) \\
4 \cdot 5(0 \cdot 7)\end{array}$ & $\begin{array}{l}126(8) \\
35(4) \\
17 \cdot 9(0 \cdot 9) \\
2 \cdot 7(0 \cdot 6)\end{array}$ & $\begin{array}{l}125(8) \\
31(4) \\
18 \cdot 2(1 \cdot 1) \\
2 \cdot 4(0 \cdot 6)\end{array}$ & $\begin{array}{l}158(13) \\
54(5) \\
17 \cdot 8(1 \cdot 9) \\
10 \cdot 4(3 \cdot 4)\end{array}$ & $\begin{array}{l}154(8) \\
60(5) \\
21 \cdot 7(1.5) \\
11 \cdot 8(2.9)\end{array}$ & $\begin{array}{l}136(11) \\
48(5) \\
18 \cdot 3(2 \cdot 0) \\
9 \cdot 1(3 \cdot 4)\end{array}$ & $\begin{array}{l}142(10) \\
51(6) \\
18 \cdot 2(1 \cdot 3) \\
12 \cdot 9(3 \cdot 1)\end{array}$ \\
\hline
\end{tabular}

* There were no significant differences between patients and hospital controls in the same age and sex category.

Conversion: SI to traditional units-Energy: $1 \mathrm{MJ} \approx 239 \mathrm{kcal}$.

TABLE IV-Best fitting set of alternative models containing dietary variables derived by conditional logistic regression analysis (patients and community controls)

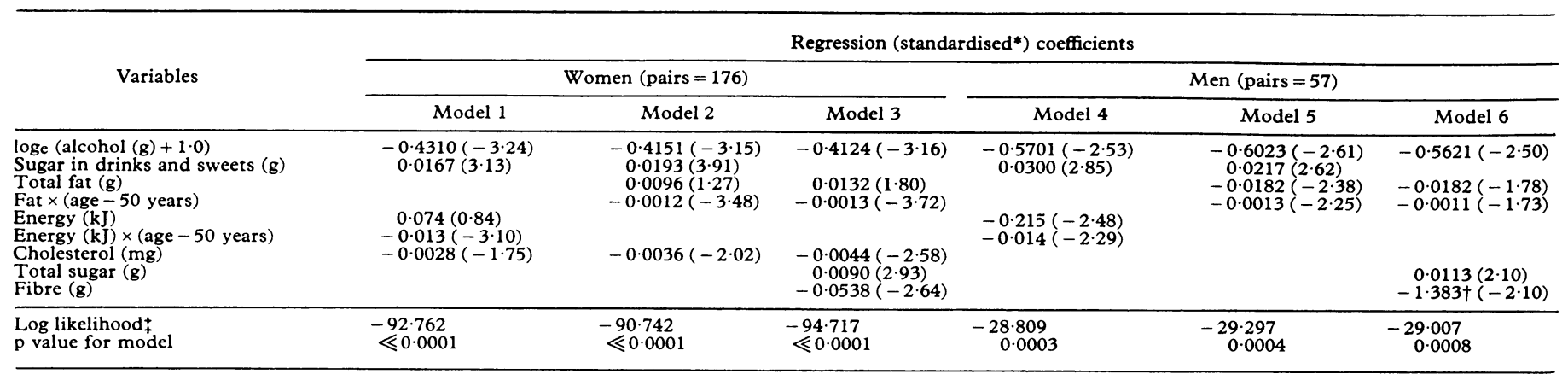

* $\mathrm{p}<0.05$ if standardised coefficient $>1.96$.

+Fibre transformed to natural logarithm.

Log likelihood of null hypothesis: $-122 \cdot 0$ for women and $-39 \cdot 51$ for men.

Conversion: SI to traditional units-1 kJ $\approx 239 \mathrm{cal}$. 
women, which became non-significant only when both Quetelet's index and household income were included. Using the regression coefficients from table IV, the decrease in risk associated with increased intake of alcohol was found to operate mostly at low levels of consumption ( $<30 \mathrm{~g} /$ day) (figure); at higher levels of consumption an increase in intake of alcohol was associated with only a small decrease in risk.

Calculations using the regression coefficients associated with energy and the energy-age interaction term for men and women (models 1 and 4 in table IV, respectively) showed that the relative risk associated with an increased intake of $2.1 \mathrm{MJ}(500 \mathrm{kcal}) /$ day was above unity at younger ages and below unity at older ages (table V). Age specific relative risks similar to those in table $\mathrm{V}$ were associated with an increase in fat intake of $20 \mathrm{~g} /$ day.

TABLE V-Estimated age specific relative risks, in patients compared with community controls, associated with increase in energy intake of $2.1 \mathrm{Mf}(500 \mathrm{kcal}) /$ day after alcohol, sugar in drinks and sweets, and cholesterol controlled for

\begin{tabular}{|c|c|c|c|c|c|c|}
\hline & \multicolumn{6}{|c|}{ Age (years) } \\
\hline & 20 & 30 & 40 & 50 & 60 & 70 \\
\hline \multirow{2}{*}{$\begin{array}{l}\text { Relative risk } \\
95 \% \text { confidence limits*: } \\
\text { Upper } \\
\text { Lower }\end{array}$} & $\begin{array}{r}W \\
2 \cdot 7\end{array}$ & $\begin{array}{c}n e n \\
2 \cdot 0\end{array}$ & 1.5 & $1 \cdot 2$ & 0.9 & 0.7 \\
\hline & $\begin{array}{l}5 \cdot 1 \\
1 \cdot 4\end{array}$ & $\begin{array}{l}3.4 \\
1.2\end{array}$ & $\begin{array}{l}2 \cdot 3 \\
1 \cdot 0\end{array}$ & $\begin{array}{l}1.7 \\
0.8\end{array}$ & $\begin{array}{l}1.3 \\
0.6\end{array}$ & $\begin{array}{l}1.1 \\
0.4\end{array}$ \\
\hline \multirow{2}{*}{$\begin{array}{l}\text { Relative risk } \\
95 \% \text { confidence limits*: } \\
\text { Upper } \\
\text { Lower }\end{array}$} & 1.5 & $n_{1 \cdot 1}$ & 0.9 & 0.6 & 0.5 & \\
\hline & $\begin{array}{l}3.0 \\
0.8\end{array}$ & $\begin{array}{l}1.8 \\
0.7\end{array}$ & $\begin{array}{l}1.2 \\
0.6\end{array}$ & $\begin{array}{l}0.9 \\
0.5\end{array}$ & $\begin{array}{l}0.8 \\
0.3\end{array}$ & $\begin{array}{l}0.7 \\
0.2\end{array}$ \\
\hline
\end{tabular}

*Derived from pooled variance of regression coefficients for energy and energy $\times$ age interaction term.

An increase in intake of sugar in drinks and sweets of $40 \mathrm{~g}$ /day (equal to 10 teaspoons of sugar or a little less than two glasses of Coca-Cola ${ }^{23}$ ) was associated with a relative risk of $2 \cdot 2(95 \%$ confidence limits $=1 \cdot 5,3 \cdot 2)$ for women and $2 \cdot 4(95 \%$ confidence limits $=1 \cdot 3,4 \cdot 6)$ for men (models 2 and 5 in table IV, respectively).

Fibre was negatively associated with the development of gall stones in both sexes, although the relation was linear in women and logarithmic in men (models 3 and 6, respectively). Calculations with regression coefficients for fibre showed that in women an increase in intake of $10 \mathrm{~g} /$ day was associated with a relative risk of $0.6(95 \%$ confidence limits $=0.4,0.9)$; in men the logarithmic relation described a similarly shaped curve to that for alcohol (figure).

Cholesterol was also negatively associated with the development of gall stones, but only in women and when included in a multivariate model with fat or energy (models 1-3, table IV). Calculations based on the regression coefficient in model 3 showed that an increased intake of cholesterol of $200 \mathrm{mg} /$ day, which is a little less than the amount of cholesterol in one egg, was associated with a relative risk of $0.4(95 \%$ confidence limits $=0 \cdot 2,0 \cdot 8)$.

Multiple logistic regression analysis of the data sets for patients and hospital controls showed that only a few nutrients had significant $(\mathrm{p}<0.05)$ regression coefficients. In women intake of energy and total fat, which were highly collinear, were each found, after age had been controlled for, to have a significant quadratic relation with the risk of developing gall stones, which was above unity over the range of intakes of nutrients recorded in this study. With increasing intake of energy or fat the risk increased to a maximum at a daily intake of $11.5 \mathrm{MJ}(2750 \mathrm{kcal})$ or $100 \mathrm{~g}$ fat before decreasing. For male patients and hospital controls intake of sugar in drinks and sweets, after age had been controlled for, also had a significant quadratic relation with the risk of developing gall stones, which increased to a maximum at $70 \mathrm{~g} /$ day before decreasing.

\section{RELATIVE WEIGHT}

Those patients (and their matched community controls), and hospital controls, who were referred for routine oral cholecystography before gastric bypass for morbid obesity were excluded from analyses in this section. Quetelet's index (weight/height ${ }^{2}$ ) was used as an index of obesity.
Among patients and community controls Quetelet's index at the time of study was significantly greater in female patients under 50 than in their matched controls; the difference between patients and controls was not significant for women over 50 or for men in either age group (table VI). A similar pattern of differences beween patients and controls existed among the four age and sex groups for Quetelet's index at age 21 (derived by dividing each subject's recollected weight at that age by his or her current height) and for the change in Quetelet's index since the age of 21. Comparison of patients with hospital controls yielded similar results with larger differences in Quetelet's index between female patients and controls aged less than 50 and no significant differences between men in either age group (table VII). These differences in Quetelet's index between patients and controls were not due to decreased physical activity in patients; physical activity in patients was found to be similar to that in controls in all categories of age and sex.

TABLE VI-Mean (SE) Quetelet's index* in patients referred either for investigation of abdominal symptoms or because of prior disease and in matched community controls

\begin{tabular}{|c|c|c|c|c|c|c|}
\hline \multirow{2}{*}{$\begin{array}{l}\text { Time of } \\
\text { measurement } \\
\text { of index }\end{array}$} & \multicolumn{3}{|c|}{ Aged $<50$ years } & \multicolumn{3}{|c|}{ Aged $\geqslant 50$ years } \\
\hline & $\begin{array}{l}\text { No of } \\
\text { pairs }\end{array}$ & Patients & Controls & $\begin{array}{l}\text { No of } \\
\text { pairs }\end{array}$ & Patients & Controls \\
\hline \multirow{2}{*}{$\begin{array}{l}\text { During study } \\
\text { At age } 21 \\
\text { Change in index } \\
\text { since age } 21\end{array}$} & $\begin{array}{l}95 \\
91\end{array}$ & $\begin{array}{l}27.3(0.6) \ddagger \\
23.6(0.5) \dagger\end{array}$ & $\begin{array}{l}\text { Women } \\
24 \cdot 2(0 \cdot 4) \\
22 \cdot 1(0 \cdot 4)\end{array}$ & $\begin{array}{l}65 \\
57\end{array}$ & $\begin{array}{l}27 \cdot 2(0 \cdot 6) \\
22 \cdot 1(0.5)\end{array}$ & $\begin{array}{l}25.8(0.5) \\
21.6(0.4)\end{array}$ \\
\hline & 91 & $3.6(0.6) \dagger$ & $2.0(0.4)$ & 57 & $4.9(0.7)$ & $4 \cdot 1(0.5)$ \\
\hline $\begin{array}{l}\text { During study } \\
\text { At age } 21 \\
\text { Change in index }\end{array}$ & $\begin{array}{l}25 \\
25\end{array}$ & $\begin{array}{l}25.8(0.9) \\
24.0(0.9)\end{array}$ & $\begin{array}{l}\text { Men } \\
26.1(0.7) \\
23.0(0.5)\end{array}$ & $\begin{array}{l}31 \\
27\end{array}$ & $\begin{array}{l}25.9(0.8) \\
22.9(0.6)\end{array}$ & $\begin{array}{l}26.2(0.6) \\
22.7(0.4)\end{array}$ \\
\hline since age 21 & 25 & $1.8(0.8)$ & $3.1(0.6)$ & 27 & $2.5(0.7)$ & $3.5(0.7)$ \\
\hline
\end{tabular}

*Weight/height ${ }^{2}\left(\mathrm{~kg} / \mathrm{m}^{2}\right)$.
Patients significantly different from matched controls: $\nmid \mathrm{p}<0.05 ; \neq \mathrm{p}<0.01$.

TABLE VII-Mean (SE) Quetelet's index* (QI) for patients and hospital controls who were referred either for investigation of abdominal symptoms or because of prior disease

\begin{tabular}{|c|c|c|c|c|c|c|c|c|}
\hline \multirow{3}{*}{$\begin{array}{l}\text { Time of } \\
\text { measurement } \\
\text { of index }\end{array}$} & \multicolumn{4}{|c|}{ Aged $<50$ years } & \multicolumn{4}{|c|}{ Aged $\geqslant 50$ years } \\
\hline & \multicolumn{2}{|c|}{ Patients } & \multicolumn{2}{|c|}{ Controls } & \multicolumn{2}{|r|}{ Patients } & \multicolumn{2}{|c|}{ Controls } \\
\hline & $\mathbf{n}$ & QI & $\mathbf{n}$ & QI & $\mathbf{n}$ & QI & $\mathbf{n}$ & QI \\
\hline $\begin{array}{l}\text { During study } \\
\text { At age } 21\end{array}$ & $\begin{array}{l}104 \\
102\end{array}$ & $\begin{array}{l}27.3(0.6) \ddagger \\
23.6(0.4) \dagger\end{array}$ & $\begin{array}{l}136^{\prime} \\
133\end{array}$ & $\begin{array}{l}\text { Tomen } \\
24 \cdot 8(0.5) \\
22 \cdot 6(0 \cdot 4)\end{array}$ & $\begin{array}{l}70 \\
61\end{array}$ & $\begin{array}{l}27.6(0.6) \dagger \\
22.5(0.5)\end{array}$ & $\begin{array}{l}76 \\
73\end{array}$ & $\begin{array}{l}25.7(0.5) \\
21.8(0.3)\end{array}$ \\
\hline $\begin{array}{l}\text { Change in index } \\
\text { since age } 21\end{array}$ & $x$ & $3.3(0.5)$ & 133 & $2 \cdot 2(0 \cdot 3)$ & 61 & $4.9(0.6)$ & 73 & $3.9(0.5)$ \\
\hline $\begin{array}{l}\text { During study } \\
\text { At age } 21\end{array}$ & $\begin{array}{l}29 \\
29\end{array}$ & $\begin{array}{l}25.9(0.8) \\
23.9(0.8)\end{array}$ & $\begin{array}{l}64 \\
61\end{array}$ & $\begin{array}{l}\text { Men } \\
24 \cdot 4(0 \cdot 4) \\
22 \cdot 9(0 \cdot 3)\end{array}$ & $\begin{array}{l}35 \\
32\end{array}$ & $\begin{array}{l}25 \cdot 7(0 \cdot 7) \\
23 \cdot 2(0 \cdot 6)\end{array}$ & $\begin{array}{l}52 \\
49\end{array}$ & $\begin{array}{l}25 \cdot 6(0.4) \\
23.2(0.4)\end{array}$ \\
\hline $\begin{array}{l}\text { Change in index } \\
\text { since age } 21\end{array}$ & 29 & $2.0(0.8)$ & 61 & $1.5(0.3)$ & 32 & $2 \cdot 4(0 \cdot 6)$ & 49 & $2 \cdot 2(0 \cdot 6)$ \\
\hline
\end{tabular}

*Weight/height ${ }^{2}\left(\mathrm{~kg} / \mathrm{m}^{2}\right)$

Patients significantly different from controls in same age and sex group: $\nmid p<0.05$; $\ddagger \mathrm{p}<0.01$.

Multivariate analysis of differences in data sets between patients and both hospital and community controls showed that, among women, Quetelet's index was significantly $(p<0.05)$ associated with the risk of developing gall stones, independently of intake of energy.

\section{Discussion}

To interpret these results the possible biases in each comparison of patients with controls must be considered. Bias may have been present in the comparison of patients with community controls as the community controls derived from a sampling frame different from that for patients. ${ }^{28}$ Such bias, however, cannot be determined on a priori grounds. ${ }^{29}$ More generally, there was likely to have been some bias in the classification of disease. Recent Australian figures for the age specific prevalence of gall stones at necropsy (department of medicine, University of Western Australia, unpublished findings) 
indicate that a maximum of $9-10 \%$ of community controls of either sex in our study may have had silent gall stones. The proportion of hospital controls with gall stones was probably higher than this because in $2-10 \%$ cholecystography may have yielded false negative results and some had probably passed stones during an attack of biliary colic.

Interviewer bias and bias in recall were unlikely in the comparison of patients with hospital controls because most subjects in hospital were interviewed double blind. Biases in classification of exposure to different foods in the comparison of patients with community controls were probably minimal because community controls were not informed of specific dietary hypotheses and the interviewer was not aware of the nutrient content of the many items of food in the frequency questionnaire.

With respect to diet and lifestyle, the hospital controls were unlikely to have been representative of people without gall stones living in the same area as the patients because most of the hospital controls had abdominal symptoms that, in part, were due to gastrointestinal diseases related to diet. The community controls, however, with an $81 \%$ response rate, were presumably representative of the local population of people free from symptoms of gall stones. Multivariate analysis showed that household income did not confound the differences in diet and obesity between patients and community controls. For these several reasons we have based the following discussion primarily on the results of comparisons between patients and community controls.

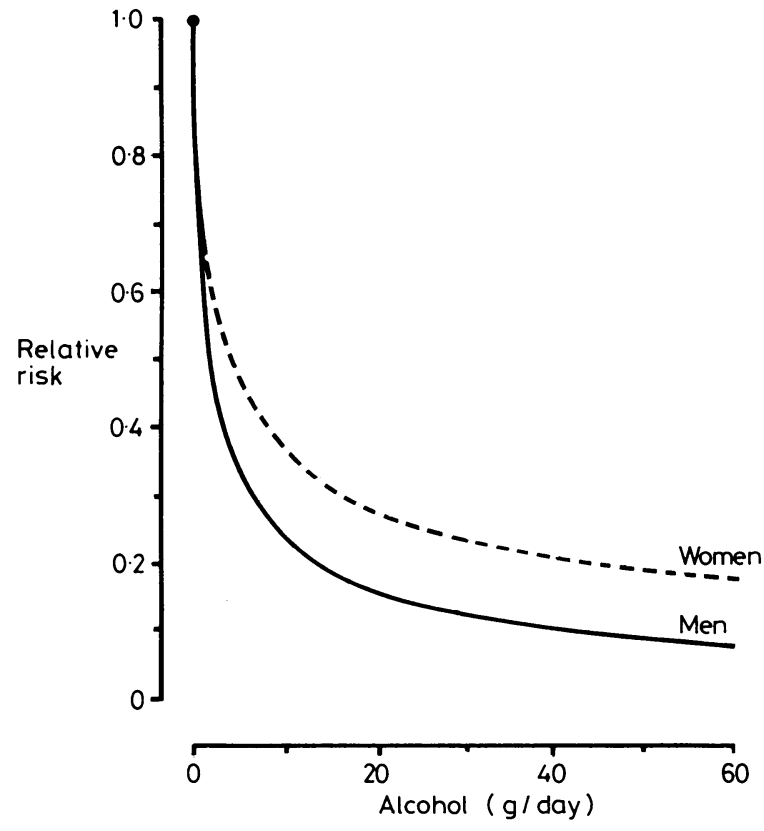

Relation between intake of alcohol and relative risk of formation of gall stones in patients compared with community controls.

\section{ALCOHOL}

The consumption of alcoholic drinks was associated with a decreased relative risk. This finding is consistent with previous studies, ${ }^{5-813}$ which generally have found a relatively lower intake of alcohol by patients than controls; similarly, an inverse relation between intake of alcohol and admission to hospital for treatment of gall stones has been reported. ${ }^{30}$

The substantial decrease in the relative risk associated with low alcohol intake, together with only small changes in risk at higher alcohol intakes (figure), suggest that an increased alcohol intake is maximally beneficial if the intake is initially low ( $<30 \mathrm{~g} /$ day). In agreement with this is the recent experimental observation in healthy human subjects with a normally low consumption of alcohol (range 0-6 $\mathrm{g} /$ day) that an increase in alcohol intake of $39 \mathrm{~g} /$ day over six weeks significantly lowered the bile cholesterol saturation index by about $20 \%{ }^{31}$

The observation that alcohol protects against the formation of gall stones may partly explain the greater prevalence of gall stones in women than men because women consume much less alcohol (tables II and III). The protective effect of alcohol may be via the liver, by increasing the conversion of cholesterol to bile acids ${ }^{32}{ }^{33}$ or by altering the enterohepatic circulation of bile acids, including deoxycholic acid, ${ }^{34}$ the concentration of which is typically raised in the bile of patients with gall stones.

\section{SUGAR}

The sugar in drinks and sweets, which was mainly sucrose, was associated with an increased risk of formation of gall stones in female and male patients relative to community controls and in male patients relative to hospital controls. The two previous case-control studies in which intake of simple sugar was measured found no significant difference between patients and controls. ${ }^{910}$ Studies of the lipid composition of bile, however, have found that a diet high in refined carbohydrates is associated with increased cholesterol saturation ${ }^{35}{ }^{36}$; a diet high in sucrose is known to produce cholesterol gall stones in hamsters. ${ }^{37}$

Intake of sucrose may increase the risk of gall stone formation by stimulating secretion of insulin. Fasting plasma insulin concentration was found in this study to be positively associated with the development of gall stones (unpublished data). Test meals given to see whether different types of simple or complex carbohydrate produce similar postprandial responses in insulin concentrations have produced conflicting results. ${ }^{38-40}$ Studies of increased intake of sucrose over several weeks show an increased fasting plasma insulin concentration and an increased insulin response to glucose..$^{41-43}$

\section{ENERGY AND FAT}

Increased intakes of energy or fat, highly correlated with each other, were associated with an increased risk of gall stones only in young patients and controls. The effects of these nutrients on the risk of developing gall stones have not previously been reported to be age dependent. Previous studies of predominantly young subjects, however, appear to support our conclusion. In three studies of women below the age of 55 patients with gall stones reported eating more than controls. ${ }^{5} 612$ In contrast, one study found that in women aged up to 60 the mean intake of energy was significantly $(p<0.05)$ lower among patients than controls. ${ }^{11}$ The age interactions associated with the intake of energy (or fat) in our study are unlikely to have been due to a cohort effect as per caput consumption of major nutrients in Australia has changed little since the 1930s. ${ }^{44}$

The observation that an increased intake of energy or fat was associated with an increased relative risk among subjects aged below 50 but a decreased risk among subjects aged 50 or more suggests that there is a subpopulation of people likely to develop gall stones, perhaps because of a genetic susceptibility or one related to lifestyle, who therefore experience a considerable increase in risk of gall stone formation in the presence of exogenous triggering factors. Among this subpopulation there would be an inverse relation between intake of energy or fat and the age at onset of gall stone disease.

The possible existence of a subpopulation susceptible to the formation of gall stones is supported by a recent report indicating that use of oral contraceptives may accelerate the formation of gall stones only in those susceptible to stone formation. ${ }^{14}$ The results of that cohort study suggested to its authors that the "short term increase in risk is due to an acceleration of gall bladder disease only in women susceptible to it." A similar increase in risk of gall stone formation associated with short 
term (6-12 months) use of oral contraceptives was observed in Boston. ${ }^{45}$ In the present study we observed age specific variations in the risk of gall stone formation associated with use of oral contraceptives and plasma triglyceride concentrations (unpublished data) that support this conclusion.

There is considerable empirical evidence of variation between individuals in the responsiveness of the metabolism of bile to changes in intake of energy, fat, cholesterol, and fibre. In patients with gall stones, but not in controls, a significant $(p<0.001)$ positive correlation exists between intake of energy and biliary cholesterol concentration over time. ${ }^{46}$ Patients with hypertriglyceridaemia, ${ }^{47}$ itself associated with an increased risk of development of gall stones (Scragg et al, unpublished data), responded differently from healthy young volunteers to polyunsaturated fats. ${ }^{489}$ The effect of dietary cholesterol on the bile saturation index varies between subjects within the same study..$^{5051}$ Bran lowers the saturation index primarily of those subjects who have a pre-existing raised saturation index. ${ }^{52-54}$

\section{FIBRE AND CHOLESTEROL}

The observed association of dietary fibre with a decreased risk of gall stone formation is less conclusive than the results for other nutrients discussed above. The relation of fibre to risk of gall stone formation is linear in women but logarithmic in men; furthermore, fibre was collinear with sugar in drinks and sweets and had a significant regression coefficient only when such sugar was excluded from logistic regression models.

The only other case-control study of gall stone formation to report intake of (crude) fibre found that it was lower in patients of both sexes and significantly $(p<0.05)$ so in women. ${ }^{11}$ The same study, however, found that intake of crude fibre $/ 4.18 \mathrm{~kJ}$ of total dietary intake was similar for patients and controls, which suggests that the quantitative differences in intake of fibre merely reflected differences in total dietary intake.

Dietary cholesterol, in multivariate analysis controlling for intake of energy or fat, was inversely associated with risk of gall stone formation in women; this finding must also be treated with caution as a similar relation was not found in men. Other case-control studies have reported that intake of cholesterol by patients and controls is similar ${ }^{1013}$ or lower in patients with cholesterol solitaire stones. ${ }^{\circ}$

\section{OBESITY}

Obesity as assessed by Quetelet's index was associated with an increased risk of gall stone formation maximally among women aged under 50 , less so among older women, and not among men. The finding of an increase in the risk of gall stone formation associated with obesity among young women is consistent with three earlier studies ${ }^{55-57}$ and with the significant $(p<0.05)$ positive association between obesity and formation of gall stones reported in those case-control studies that examined women aged below 50 exclusively. ${ }^{12} 58$ Sarles et al, however, studying women aged $20-55$, failed to find a positive association between formation of gall stones and obesity. ${ }^{5}$ The association between Quetelet's index and risk of gall stone formation was independent of intake of energy among women aged below 50, suggesting that obesity among young female patients, compared with their controls, was predominantly due to non-dietary factors.

The finding that obesity was not a significant risk factor among women aged 50 or more or among men of all ages could reflect an influence of reproductive or hormonal factors, or both, in the association between obesity and gall stones. The interaction of Quetelet's index with age in the risk of gall stone formation among women could also indicate that obesity in young and middle adulthood is associated with a progressive depletion, with increasing age, of the subpopulation constitutionally susceptible to gall stone formation.

\section{CONCLUSIONS}

In summary, we found, in a large case-control study, that increased intake of alcohol was associated with a substantially decreased risk of development of gall stones, increased intake of sugar in drinks and sweets with an increased risk, and increased intake of energy (or fat) with an increased risk at young ages only. Furthermore, obesity increased the risk of formation of gall stones primarily in young women but not in men.

We thank Professor James Watts and Dr Malcolm Whiting for guidance; Dr Gerald Davies for help; the staff of the radiology departments at Flinders Medical Centre and Queen Elizabeth Hospital for their cooperation while interviewing patients; $\mathrm{Dr}$ Katrine Baghurst for constructing the dietary frequency questionnaire; Ms Sally Record for programming; and the study subjects for their time.

\section{References}

${ }^{1}$ Brett M, Barker DJP. The world distribution of gallstones. Int $\mathcal{F}$ Epidemiol $1976 ; 5: 335-41$.

2 Bennion LJ, Grundy SM. Risk factors for the development of cholelithiasis in man-part 2. N Engl f Med 1978;299:1221-7.

${ }^{3}$ Sarles H, Chalvet H, Ambrosi L, D'Ortoli G. Etude statistique des facteurs diététiques dans la pathogénie de la lithiase biliaire humaine. Sem Hop Paris 1957;58:3424-8.

4 Hauton J. Cholelithiasis. Third World Congress of Gastroenterology, Tokyo. Recent Adv Gastroenterol 1966;4:109-16.

${ }^{5}$ Sarles H, Chabert C, Pommeau Y, et al. Diet and cholesterol gallstones. A study of 101 patients with cholelithiasis compared to 101 matched controls. Am ₹ Dig Dis 1969;14:531-7.

6 Sarles H, Gerolami A, Bord A. Diet and cholesterol gallstones. A further study. Digestion 1978;17:128-34.

7 Coste T, Karsenti P, Berta JL, Cubeau J, Guilloud-Bataille M. Facteurs diététiques de la lithiase biliaire: comparaison de l'alimentation d'un groupe de lithiasiques à l'alimentation d'un groupe témoin. Gastroenterol Clin Biol 1979;3:417-24.

${ }^{8}$ Wheeler M, Hills LL, Laby B. Cholelithiasis: a clinical and dietary survey. Gut 1970;11:430-7.

${ }^{9}$ Burnett W. The epidemiology of gallstones. Tijdschr Gastroenterol 1971; $14: 79-89$.

10 Reid JM, Fullmer SD, Pettigrew KD, et al. Nutrient intake of Pima Indian women: relationships to diabetes mellitus and gallbladder disease. Am $\mathcal{F}$ Clin Nutr $1971 ; 24: 1281-9$.

11 Smith DA, Gee MI. A dietary survey to determine the relationship between diet and cholelithiasis. Am $\mathcal{F}$ Clin Nutr 1979;32:1519-26.

12 Williams CN, Johnston JL. Prevalence of gallstones and risk factors in Caucasian women in a rural Canadian community. Can Med Assoc $\mathcal{F}$ 1980;120:664-8.

${ }^{13}$ Friedman GD, Kannel WB, Dawber TR. The epidemiology of gallbladder disease: observations in the Framingham study. $f$ Chronic Dis 1966; 19:273-92.

14 Royal College of General Practitioners' Oral Contraception Study. Oral contraceptives and gallbladder disease. Lancet 1982;ii:957-9.

15 Gough MH. "The cholecystogram is normal" . . . but .... Br Med F $1977 ; \mathrm{i}: 960-2$.

${ }^{16}$ Goldberg BB, Harris $\mathrm{K}$, Broocker W. Ultrasonic and radiographic cholecystography. A comparison. Radiology 1974;111:405-9.

17 DeGraaff CS, Dembner AG, Taylor JW. Ultrasound and the false normal oral cholecystogram. Arch Surg 1978;113:877-9.

18 Margulies SI, Brogdon BG, Sindler RA, Perilla FR. Disappearing gallstones. Br $\mathcal{F}$ Radiol 1967;40:546-9.

19 Gray R. Disappearing gallstones: report of 2 cases. Br $\mathcal{F}$ Surg 1974;61 : 101-3.

${ }^{20}$ Baghurst KI, Baghurst PA. The measurement of usual dietary intake in individuals and groups. Transactions of the Menzies Foundation 1.981 3:139-60.

${ }^{21}$ Morgan RW, Jain M, Miller AB, et al. A comparison of dietary methods in epidemiologic studies. Am F Epidemiol 1978;107:488-98.

22 Bazzarre TL, Myers MP. The collection of food intake data in cancer epidemiology studies. Nutr Cancer 1979;1:22-45.

${ }^{23}$ Paul AA, Southgate DAT. McCance and Widdowson's the composition of foods. London: HMSO, 1978.

24 Thomas S, Corden M. Tables of composition of Australian foods. Canberra: Commonwealth Department of Health, 1970.

${ }^{25} \mathrm{Nie} \mathrm{NH}$, Hull CH, Jenkins JG, et al. Statistical package for the social sciences. 2nd ed. New York: McGraw-Hill, 1975.

26 Breslow NE, Day NE. Statistical methods in cancer research. Vol 1. The analysis of case-control studies. Lyons: IARC Scientific Publications, 1980. (IARC No 32.)

27 Thomas DC. General relative-risk models for survival time and matchec case-control analysis. Biometrics $1981 ; 37: 673-86$.

${ }^{28}$ Feinstein AR. Methodologic problems and standards in case-control research. $\mathcal{f}$ Chronic Dis $1979 ; 32: 35-41$. 
${ }^{29}$ Greenland S, Neutra R. An analysis of detection bias and proposed corrections in the study of estrogens and endometrial cancer. $\mathcal{F}$ Chronic Dis $1981 ; 34: 433-8$.

30 Klatsky AL, Friedman GD, Siegelaub AB. Alcohol use and cardiovascular disease: the Kaiser-Permanente experience. Circulation 1981;64, suppl III :32-41.

31 Thornton J, Symes C, Heaton K. Moderate alcohol intake reduces bile cholesterol saturation and raises HDL cholesterol. Lancet 1983;ii : 819-22.

32 Nestel PJ, Simons LA, Homma Y. Effects of ethanol on bile acid and cholesterol metabolism. Am f Clin Nutr 1976;29:1007-15.

33 Topping DL, Weller RA, Nader CJ, et al. Adaptive effects of dietary ethanol in the pig: changes in plasma high-density lipoproteins and fecal steroid excretion and mutagenicity. Am $\mathcal{f}$ Clin Nutr 1982;36: 245-50.

34 Yoshida T, McCormick WC, Swell L, Vlahcevic ZR. Bile acid metabolism in cirrhosis. IV. Characterization of the abnormality in deoxycholic acid metabolism. Gastroenterology 1975;68:335-41.

35 Williams CN, Scallion SM, McCarthy SC. A diet containing highly refined carbohydrate will adversely change bile lipid composition to that seen in cholesterol gallstone disease. Ann $R$ Coll Phys Surg Canado 1979;12:44.

36 Thornton JR, Emmett PM, Heaton KW. Diet and gall stones: effects of refined and unrefined carbohydrate diets on bile cholesterol saturation and bile acid metabolism. Gut 1983;24:2-6.

37 Dam $\mathrm{H}$, Christensen $\mathrm{F}$. Alimentary production of gallstones in hamsters. Acta Pathol Microbiol Scand 1952;30:236-41.

"Swan DC, Davidson P, Albrink MJ. Effect of simple and complex carbohydrates on plasma non-esterified fatty acids, plasma sugar, and plasma insulin during oral carbohydrate tolerance tests. Lancet 1966; i: $60-3$.

${ }^{3 y}$ Wahlqvist ML, Wilmshurst EG, Murton CR, Richardson EN. The effect of chain length on glucose absorption and the related metabolic response. Am f Clin Nutr 1978;31:1998-2001.

11) Crapo PA, Scarlett JA, Kolterman OG. Comparison of the metabolic responses to fructose and sucrose sweetened foods. Am $\mathrm{f}$ Clin Nutr $1982 ; 36: 256-61$.

"Reiser S, Handler HB, Gardner LB, et al. Isocaloric exchange of dietary starch and sucrose in humans. II. Effect on fasting blood insulin, glucose, and glucagon and on insulin and glucose response to a sucrose load. Am 7 Clin Nutr 1979 ;32:2206-16.

12 Reiser S, Bohn E, Hallfrisch J, et al. Serum insulin and glucose in hyperinsulinemic subjects fed three different levels of sucrose. $\mathrm{Am} \mathcal{f} \mathrm{Clin}$ Nutr $1981 ; 34: 2348-58$

${ }^{13}$ Coulston A, Greenfield MS, Kraemer FB, et al. Effect of differences in source of dietary carbohydrate on plasma glucose and insulin responses to meals in patients with impaired carbohydrate tolerance. Am $\mathcal{F}$ Clin Nutr $1981 ; 34: 2716-20$.

" McMichael AJ, Potter JD, Hetzel BS. Time trends in colo-rectal cancer mortality in relation to food and alcohol consumption: United States, United Kingdom, Australia and New Zealand. Int 7 Epidemiol 1979; 8:295-303.

${ }^{15}$ Boston Collaborative Drug Surveillance Programme. Oral contraceptives and venous thromboembolic disease, surgically confirmed gall-bladder disease, and breast tumours. Lancet 1973;i:1399-404.

16 Sarles H, Hauton J, Planche N, Lafont H, Gerolami A. Diet, cholesterol gallstones, and composition of the bile. Am F Dig Dis 1970;15:251-60.

${ }^{17}$ Grundy SM. Effects of polyunsaturated fats on lipid metabolism in patients with hypertriglyceridemia. 7 Clin Invest 1975;55:269-82.

48 Dam H, Kruse I, Jensen K, Kallehauge HE. Studies on human bile. II. Influence of two different fats on the composition of human bile. Scand $\mathcal{F}$ Clin Lab Invest 1967;19:367-78.

19 Schlierf G, Nikolaus T, Stiehl A, et al. Zur Wirkung lipidspiegelsenkender Kostformen auf Gallenlipide und Plasmalipoproteine bei Normalpersonen. Schweiz Med Wochenschr 1979;109:1743-7.

${ }^{50}$ Dam H, Prange I, Jensen K, et al. Studies on human bile. IV. Influence of ingestion of cholesterol in the form of eggs on the composition of bile in healthy subjects. $Z$ Ernahrungswiss $1971 ; 10: 178-87$.

${ }^{51}$ Andersen E, Hellstrom K. The effects of cholesterol feeding on bile acid kinetics and biliary lipids in normolipidemic and hypertriglyceridemic subjects. F Lipid Res 1979;20:1020-7.

52 Pomare EW, Heaton KW, Low-Beer TS, Espiner HJ. The effect of wheat bran upon bile salt metabolism and upon the lipid composition of bile in gallstone patients. Am F Dig Dis 1976;21:521-6.

${ }^{53}$ McDougall RM, Yakymyshyn L, Walker K, Thurston OG. Effect of wheat bran on serum lipoproteins and biliary lipids. Can $\mathcal{F}$ Surg 1978; $21: 433-5$

${ }^{54}$ Watts J McK, Jablonski P, Toouli J. The effect of added bran to the diet on the saturation of bile in people without gallstones. Am F Surg 1978; $135: 321-4$.

${ }^{55}$ Horn G. Observations on the aetiology of cholelithiasis. $\mathrm{Br} \mathrm{Med} \mathcal{F} 1956$; ii:732-7.

${ }^{56}$ Bernstein RA, Werner LH, Rimm AA. Relationship of gallbladder disease to parity, obesity, and age. Health Serv Rep 1973;88:925-36.

57 Newman $\mathrm{HF}$, Northup JD. The autopsy incidence of gallstones. Int Abstr Surg (issued with Surg Gynecol Obstet) 1959;109:1-13.

${ }^{58}$ Honore LH. Cholesterol cholelithiasis in adolescent females. Its connection with obesity, parity, and oral contraceptive use-a retrospective study of 31 cases. Arch Surg 1980;115:62-4.
St Thomas's Hospital, London

S CHAL.LAH, MB, BCHIR, registrar in community medicine

A J WING, DM, FRCP, consultant physician, chairman, EDTA Registration committee

R BAUER, MD, MSC, Millbank scholar, department of community medicine $R$ W MORRIS, MSC, lecturer in medical statistics, department of community medicine

S A SCHROEDER, MD, visiting professor, department of community medicine

Correspondence to: Dr S Challah, EDTA, St Thomas's Hospital, London SE1 7EH. and medical problems. In each case the responding doctor was asked to indicate whether the patient would be suitable for treatment by dialysis or transplantation or both. The questionnaire was sent to a randomly selected sample of general practitioners and non-renal consultant physicians and their responses compared with those of all the nephrologists identified in the United Kingdom.

The mean number of cases rejected by both general practitioners and non-renal consultant physicians was significantly higher than the number rejected by nephrologists. The findings suggest that underreferral of patients to dialysis and transplant units contributes to the current low acceptance rate of new patients into treatment programmes in the United Kingdom.

\section{Introduction}

The United Kingdom ranks low in the treatment of end stage renal failure by dialysis and transplantation (see table I). In 1981 only $26 \cdot 7$ new patients per million population were accepted into 